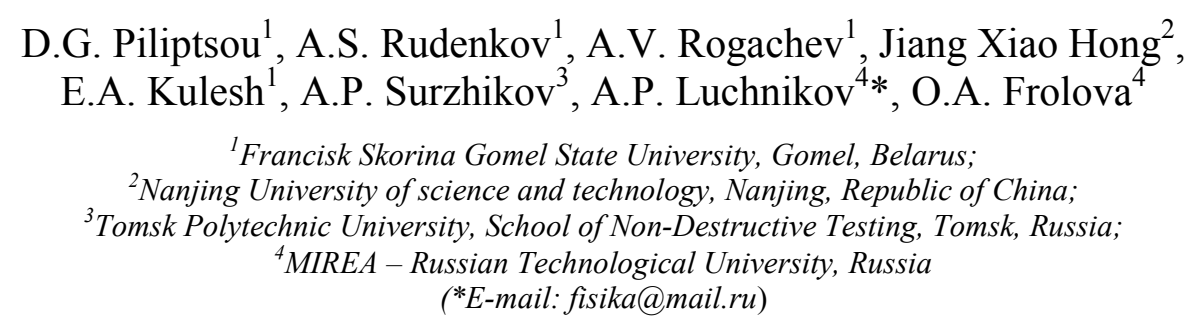

\title{
Structural properties of carbon composites doped with boron
}

\begin{abstract}
The article considers morphology, chemical and phase composition of composite boro-carbon coatings, received by ion-plasma synthesis, depending on the boron content. Specimens of carbon coating doped with boron were obtained in vacuum unit by combined method coupled with co-deposition of carbon layer from pulse carbon plasma and its doping with boron atom flow. The obtained specimens of composite $\mathrm{CC}$ had embedded boron atoms with various concentration $\left(\mathrm{N}_{\mathrm{B}}\right)$, namely, 2.3 at.\% were contained in $\mathrm{a}-\mathrm{C}_{91.2}: \mathrm{B}_{2.3}$, in $\mathrm{a}-\mathrm{C}_{79.3}: \mathrm{B}_{17.4}-17.4$ at.\%, in $\mathrm{a}-\mathrm{C}_{53.3}: \mathrm{B}_{43.2}-43.2$ at.\%. Carbon structures and carbon clusters graphitization were examined by X-ray photoelectron spectroscopy and Raman spectroscopy. Aiming at chemical interaction between carbon and boron in CC establishment we conducted mathematical processing of XPS for energy states $\mathrm{C} 1 \mathrm{~s}, \mathrm{~B} 1 \mathrm{~s}, \mathrm{O} 1 \mathrm{~s}$ of carbon, boron and oxygen atoms. XPS C1s was presented as peaks superposition with centers located at $284.5 ; 285.5 ; 283.5$ and $288 \mathrm{eV}$ and consequently responsible for $\mathrm{Csp}^{2}, \mathrm{Csp}^{3}, \mathrm{C}-\mathrm{B}$ and $\mathrm{C}-\mathrm{O}$ carbon atom interaction. With the growth of $\mathrm{N}_{\mathrm{B}}$ in boron-doped carbon coating a grain structure is formed, its size and grain orientation regarding the surface of the substrate increase, resulting in a decrease in the coating layer surface roughness.
\end{abstract}

Keywords: composite carbon coatings, boron droping, atomic force microscopy, X-ray photoele tron spectroscopy, Raman spectroscopy, clusters, boron carbide.

\section{Introduction}

Boron doping is considered to be an effective technological method of improving operational metal resources and their alloys [1]. Boron being the second solid element and having metal matrix in the volume as a separate phase, solid solution or chemical compound, deforms crystalline lattice and causes solid phase formation in materials that significantly increase their mechanical properties, thermal and wear resistance [2]. Boron on contact with carbon can form chemically stable boron carbide $\mathrm{B}_{4} \mathrm{C}$, which is resistant at temperature up to $2450{ }^{\circ} \mathrm{C}$. These characteristics of boron determine high prospectivity of its use as a doping element in forming compositional carbon-contained coatings [3]. On [4] it is indicated, that phase and structural characteristics of such coatings are significantly defined by conditions and regimes of their formation by means of ion-plasma synthesis. In implementing of carbon layers' deposition methods from pulse cathode plasma, intensive thermal excitation processes are carried out, ionized particles streams having sufficiently high reaction activity are formed. At the same time carbon layers are condensed in the form of heterophase coatings containing carbon atoms in the state of sp3, sp2 and even sp1-hybridized bonds. Such features of carbon coating (CC) deposition suggest that when they are doped with boron in the process of ion plasma synthesis it is possible to form a wide range of different phases in the layer structure, including based on chemical compounds. Composite materials with clusters from compounds on the basis of doping substance can have the same structure as nanocomposites based on polymer matrix [5].

The article considers structural properties of composite boron-carbon coatings obtained by ion-plasma synthesis based on their boron content.

\section{Samples and research methods}

Specimens of CC doped with boron were obtained in vacuum unit by combined method coupled with co-deposition of carbon layer from pulse carbon plasma and its doping with boron atom flow. Target evaporation from boron was conducted by pulsed radiation from solid-state $\mathrm{YAG}: \mathrm{Nd}^{3+}$ laser at wavelength $1,064 \mathrm{~nm}$ in the frequency range of $\left(\mathrm{f}_{\mathrm{L}}\right) 5$ to $50 \mathrm{~Hz}$. Boron atoms flow with pulse length $150 \mu$ s and frequency $\mathrm{f}_{\mathrm{L}}=5,30$ and $50 \mathrm{~Hz}$ was deposited on $\mathrm{CC}$ surface together with carbon plasma flow from vacuum-arc evaporator with pulse length $150 \mu$ s and frequency $\mathrm{f}_{\mathrm{C}}=10 \mathrm{~Hz}$. 
The elemental composition of the obtained a-C:B CC was regulated through changing of laser radiation pulse frequency $\mathrm{f}_{\mathrm{L}}$ and was determined by X-ray photoelectron spectroscopy (XPS). X-ray photoelectron spectra of obtained carbon coatings were shot using PHI Quanta type, Japan.

The obtained specimens of composite $\mathrm{CC}$ had embedded boron atoms with various concentration $\left(\mathrm{N}_{\mathrm{B}}\right)$, namely, 2.3 at.\% were contained in $\mathrm{a}-\mathrm{C}_{91.2}: \mathrm{B}_{2.3}$, in $\mathrm{a}-\mathrm{C}_{79.3}: \mathrm{B}_{17.4}-17.4$ at.\%, in $\mathrm{a}-\mathrm{C}_{53.3}: \mathrm{B}_{43.2}-43.2$ at.\%.

Carbon coating thickness was defined by means of transversal specimen chip with the help of scanning electron microscope (SEM) of Hitachi S-4800 type. A comparative analysis was carried out on CC specimens with the same effective thickness $363 \pm 16 \mathrm{~nm}$. Surface morphology of composite carbon coatings $\mathrm{a}-\mathrm{C}$ :B was investigated with the help of atomic-force microscope (AFM) of Solver Pro and NT-MDT (Russia) types in topography and phase contrast measuring mode. The scanning field was $10 \times 10 \mu \mathrm{m}^{2}$ at probe speed of $1.0 \mu \mathrm{m} / \mathrm{s}$. High heterogeneous projections on the surface were monitored using the methods [6].

The microstructure of composite CC was studied by Raman spectroscopy at radiation excitation at wavelength $532 \mathrm{~nm}$ with power flow $20 \mathrm{~mW}$ using Senterra, Bruker.

The chemical composition and types of molecular bonds between carbon and boron atoms in the composite CC were determined by X-ray photoelectron spectroscopy using a PHI quantera 2 XPS device. XPS spectra were excited by $\mathrm{Al}(\mathrm{Ka})$ cathode emission with the energy of $1486.6 \mathrm{eV}$ at a voltage of $15 \mathrm{~kW}$. The capacity of exciting radiation power was $25 \mathrm{~W}$. The spectrum was collected in the area of interaction of the probing radiation with the surface of a spot CC specimen with a diameter of $100 \mu \mathrm{m}$. Bonds energy in XPS spectra was calibrated through $\mathrm{C} 1 \mathrm{~s}(284.6 \mathrm{eV})$. It should be noted that since the atomic sensitivity coefficient for boron (0.088) is significantly lower than for carbon C (0.205), the intensity of the B1s peak in XPS spectrum is significantly lower than that of the $\mathrm{C} 1 \mathrm{~s}$ peak.

\section{Experimental results and their discussion}

On Figure 1 SEM-images of CC specimen chip doped with boron are represented. It is seen that the structure of $\mathrm{CC}$ doped with boron differs from the structure of one-component a-C coating (Fig. 1, $a$ ). In the volume a-C:B of $\mathrm{CC}$ the formation of grain structure occurs, what is more, grain size depends on boron concentration $\mathrm{N}_{\mathrm{B}}$ and increases with its growth: at a concentration $\sim 2.3$ at. \% the structure becomes finegrained, with its further growth $\mathrm{N}_{\mathrm{B}}$ achieves $\sim 43.2$ at. \% with grain formation in 3-3.5 times larger with marked orientation towards substrate surface [7]. There are no defects like pores or cracks on the surface and in the volume of deposited composite CC, as well as there are no substrate layers. The latter shows high adhesion of CC to silicon substrate.

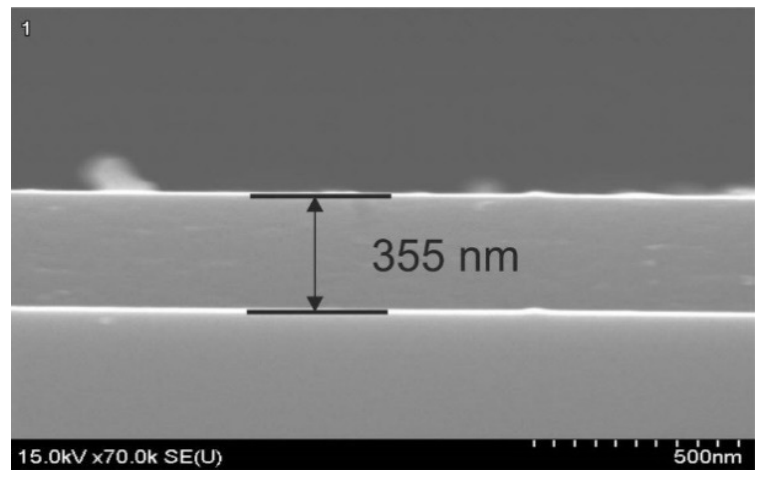

$a$

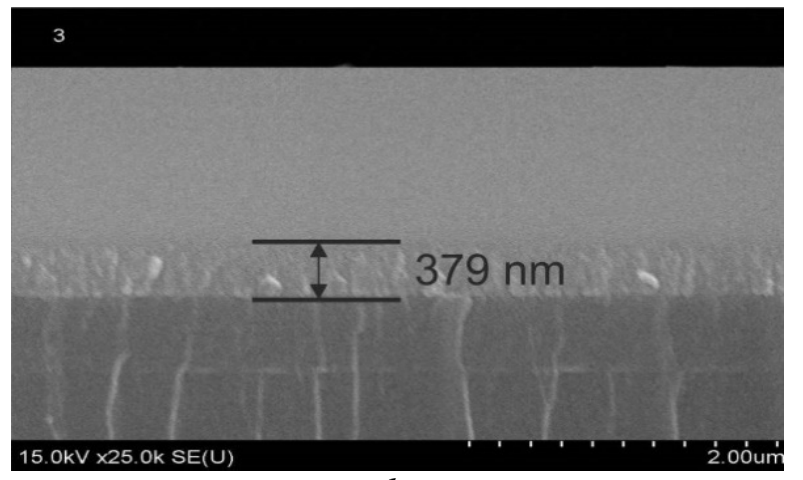

$b$

Figure 1. SEM-images of chip a-C $(a)$ and $\mathrm{a}-\mathrm{C}_{53.3}: \mathrm{B}_{43.2}(b)$ of CC

On Figure 2 dependancy diagram of $\mathrm{N}_{\mathrm{C}}$ content of carbon component (curve 1) and average size of grain $\left(\mathrm{R}_{\mathrm{g}}\right)$ in $\mathrm{CC}$ doped with boron is shown. The composition of elements of CC specimens, deposited together from pulse carbon plasma and boron atom flow doped with boron concentration 2.3 at.\%, 17.4 at.\% and 43.2 at.\% with dopant boron atom flow frequency $\mathrm{f}_{\mathrm{L}}$ increase changes essentially. Oxygen in CC structure is within the limits $2.4 \ldots 6.5$ at. \% and in bound state with carbon mainly.

It can be seen that $\mathrm{N}_{\mathrm{B}}$ increase in the coating leads to higher defectiveness of the composite $\mathrm{CC}$ and the formation of larger surface heterogeneities. Grain structure increase of boron-doped CC is caused by high activity of agglomeration processes with formation of boron in initial one-component carbon material. Grain 
size increase $\mathrm{R}_{\mathrm{g}}$ in boron-carbon coating with higher boron content $\mathrm{N}_{\mathrm{B}}$ is consistent with diamond-like films morphology data [8].

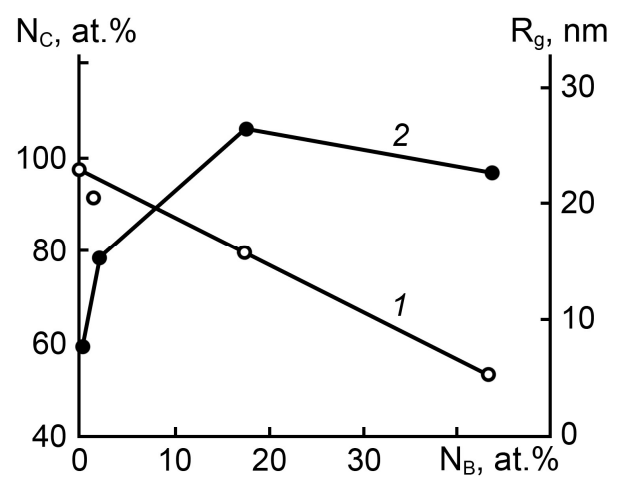

Figure 2. Dependancy diagram of carbon component $\mathrm{N}_{\mathrm{C}}$ content (1) and grain $\mathrm{R}_{\mathrm{g}}$ average size (2) in $\mathrm{CC}$ structure on $\mathrm{N}_{\mathrm{B}}$ concentration of dopant boron atoms.

It should be noted that geometric parameters of CC structural state, surface roughness $\left(\mathrm{R}_{\mathrm{ms}}\right)$ and grain $\mathrm{R}_{\mathrm{g}}$ average size of the layer structure depend on conditions and modes of the coating process. Thus, onecomponent a-C of $\mathrm{CC}$, deposited from pulse flows, are characterized by low values $\mathrm{R}_{\mathrm{ms}}$, that can be explained by small sizes and clusters close packing $\mathrm{Csp}^{3}[9]$.

On Figure 3 typical Raman spectra a-C $(a)$ and $a-C_{53.3}: \mathrm{B}_{43}(b)$ of $\mathrm{CC}$ are presented. Raman spectra (RS) envelope shape of all $\mathrm{CC}$ is peculiar to amorphous $\mathrm{CC}$, containing carbon atoms both in $\mathrm{sp}^{2}$ and $\mathrm{sp}^{3}$ bond hybridization state.

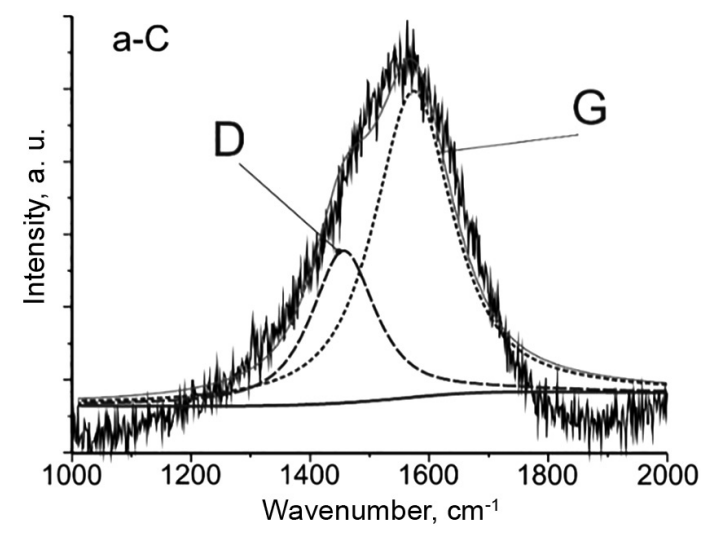

$a$

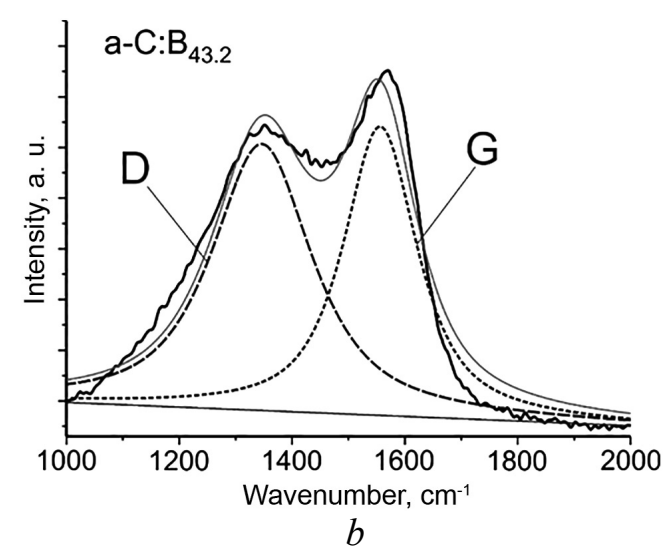

$b$

Figure 3. Raman-spectra a-C $(a)$ and a- $\mathrm{C}_{53.3}: \mathrm{B}_{43}(b)$ of CC

Figure 3 shows that RS of boron-carbon CC have broad asymmetric peak in the range 1000 to $2000 \mathrm{~cm}^{-1}$, that according to [10] contains information about $\mathrm{sp}^{2}$ hybridized carbon bonds, order degree and relative size of carbon clusters $\mathrm{Csp}^{2}$ and $\mathrm{Csp}^{3}$. Raman spectrum can be represented in superposition of peaks (G-peak and D-peak) by Gaussian function. Herewith theoretical curve, being the result of spectrum simulation, is well consistent to basic experimental data that testifies the certainty of RS mathematical processing.

With $\mathrm{N}_{\mathrm{B}}$ growth in CC changes of RS relative to intensity ratio of D- and G-peaks occur (Fig. 3, Table 1), that are determined not only by changes of $\mathrm{Csp}^{2}$ and $\mathrm{Csp}^{3}$ clusters quantity and size in accordance with [11], but also by metal content in the layer, its chemical activity. There is molecular bonds process between carbon and boron that leads to changes of carbon clusters degree of order.

It was found that at $\mathrm{N}_{B}=2.3$ at. \% in carbon coating D- and G-peaks intensity ratio insignificantly changes in comparison with RS parameters of one-component carbon coating. It indicates little impact of small $\mathrm{N}_{\mathrm{B}}$ on the ordering degree and relative distribution of $\mathrm{Csp}^{2} / \mathrm{Csp}^{3}$ carbon phases in the coating.

With $\mathrm{N}_{\mathrm{B}}$ growth in CC D-peak intensity increase occurs, as well as G-peak centreshift towards lower values of wave numbers. Essential changes of RS shape and $\mathrm{I}_{\mathrm{D}} / \mathrm{I}_{\mathrm{G}}$ ratio increase (Table 1) for carbon coatings a-C highly doped with boron (Fig. 3, b) $\left(\mathrm{N}_{\mathrm{B}}=43.2\right.$ at. \%) happen. 
Parameters of the Raman spectra of carbon coatings doped with boron

\begin{tabular}{|c|c|c|c|c|c|c|c|}
\hline Type of CC & $\mathrm{f}_{\mathrm{L}}, \mathrm{Hz}$ & $\mathrm{N}_{\mathrm{C}}$, at.\% & $\mathrm{N}_{\mathrm{B}}$, at.\% & $\mathrm{N}_{\mathrm{O}}$, at.\% & $\mathrm{I}_{\mathrm{D}} / \mathrm{I}_{\mathrm{G}}$ & $\begin{array}{c}\text { Position of } \\
\text { G-peak, } \mathrm{cm}^{-1}\end{array}$ & $\begin{array}{c}\text { Width of } \\
\text { G-peak, } \mathrm{cm}^{-1}\end{array}$ \\
\hline $\mathrm{a}-\mathrm{C}$ & - & 97.6 & - & 2.4 & 0.58 & 1573.5 & 157.2 \\
\hline $\mathrm{a}-\mathrm{C}_{91.2}: \mathrm{B}_{2.3}$ & 5 & 91.2 & 2.3 & 6.5 & 0.62 & 1571.3 & 168.7 \\
\hline $\mathrm{a}-\mathrm{C}_{79.3}: \mathrm{B}_{17.4}$ & 33 & 79.3 & 17.4 & 3.3 & 0.73 & 1552.3 & 189.9 \\
\hline $\mathrm{a}-\mathrm{C}_{53.3}: \mathrm{B}_{43.2}$ & 50 & 53.3 & 43.2 & 3.5 & 1.25 & 1556.2 & 155.7 \\
\hline
\end{tabular}

In accordance with [12] CC received from pulse flows of carbon plasma are characterized by high mechanical properties under the condition $\left(\mathrm{I}_{\mathrm{D}} / \mathrm{I}_{\mathrm{G}}\right) \leq 1$ and for $\mathrm{CC}$ a-C carbon atom concentration with sp ${ }^{3}$ hybridized bonds increases with $\mathrm{I}_{\mathrm{D}} / \mathrm{I}_{\mathrm{G}}$ ratio reduction. According to Table 1 with $\mathrm{N}_{\mathrm{B}}$ growth up to 17.4 at. \% some $\mathrm{I}_{\mathrm{D}} / \mathrm{I}_{\mathrm{G}}$ ratio increase is observed in the coating, that indicates the reduction of carbon atom concentration with $\mathrm{sp}^{3}$ hybridized bonds.

Together with the increase of $I_{D} / I_{G}$ ratio G-peak shifting toward lower wave numbers in comparison with peak's position for $\mathrm{CC}$ a-C takes place. According to [13] such change corresponds to the decrease of carbon matrix ordering degree and is defined by carbon atom concentration degree with $\mathrm{sp}^{3}$ hybridized bonds. Based on data from Table 1 we can conclude that the shifting of G-peak position and insignificant value increase of $\mathrm{I}_{\mathrm{D}} / \mathrm{I}_{\mathrm{G}}$ ratio, typical of $\mathrm{CC}$ a-C with $\mathrm{N}_{\mathrm{B}}=2.3$ at. $\%$ and 17.4 at. $\%$, are caused by the concentration growth of $\mathrm{CC} \mathrm{Csp}^{3}$. In [12] it is shown that the increase in carbon atoms number in $\mathrm{sp}^{3}$ hybridized bonds is probably connected with $\mathrm{C}-\mathrm{B}$ bonds formation in $\mathrm{CC}$, while boron interacts mainly with carbon atoms with $\mathrm{sp}^{3}$ hybridization. It leads to the growth of structural heterogeneity that causes the ordering degree decrease of carbon clusters $\mathrm{Csp}^{2}$ and shows in $\mathrm{RS}$ of $\mathrm{CC}$ as G-peak broadening. At high $\mathrm{N}_{\mathrm{B}}$ value the density reduction of $\mathrm{sp}^{3}$ bonds occurs in CC.

$\mathrm{X}$-ray photoelectron spectroscopy (XPS) analysis for $\mathrm{CC}$ a-C and a-C:B presented on Figure 4 shows that except boron there is also oxygen in the surface layer in the bond state with carbon $(\mathrm{C}-\mathrm{O})$ and boron (B-O). These bonds are formed at the stage of CC deposition as a result of interaction of carbon and boron components with oxygen in the operating environment of the vacuum chamber, as well as at its depressurization. Since the contribution of oxygen $\mathrm{C}-\mathrm{O}$ and $\mathrm{B}-\mathrm{O}-$ bonds to the integrated intensity was insignificant in relation to the total basic peaks area, their impact on $\mathrm{CC}$ structure and properties was not studied.
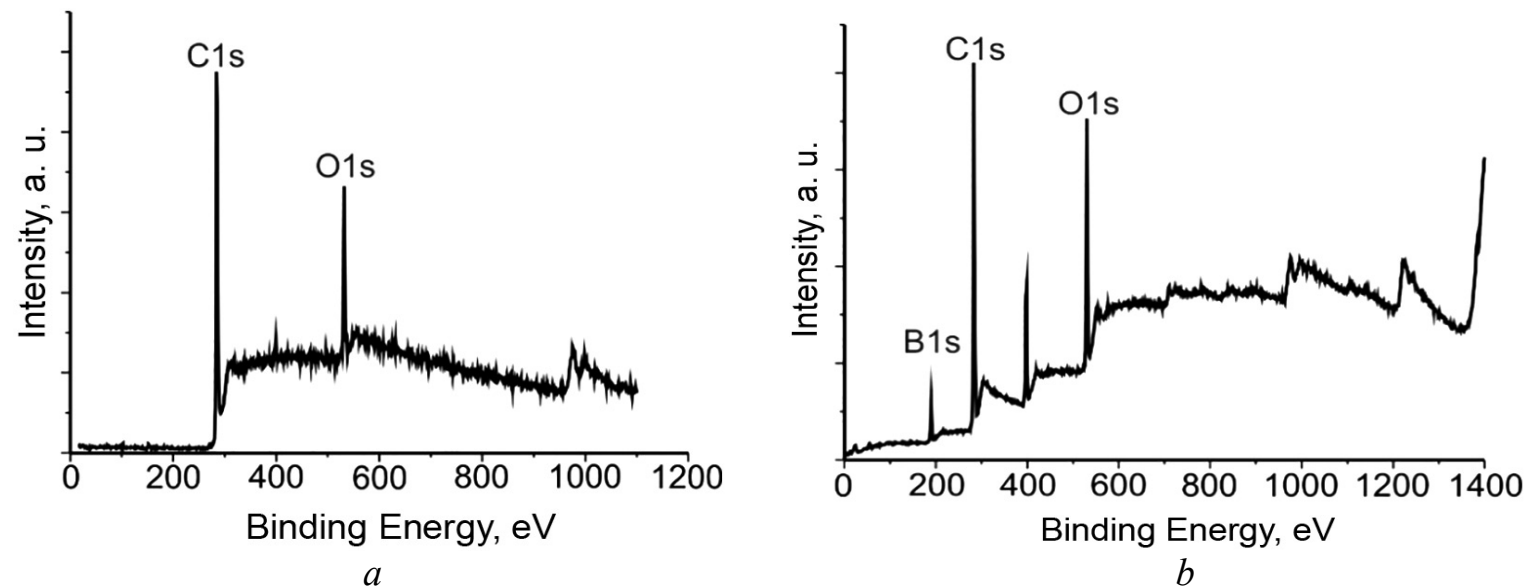

Figure 4. XPS a-C ( $a$ ) and a-C: $\mathrm{B}_{43.2}(b) \mathrm{CC}$

Aiming at chemical interaction between carbon and boron in CC establishment we conducted mathematical processing of XPS for energy states $\mathrm{C} 1 \mathrm{~s}, \mathrm{~B} 1 \mathrm{~s}, \mathrm{O} 1 \mathrm{~s}$ of carbon, boron and oxygen atoms. XPS C1s was presented as peaks superposition with centers located at $284.5 ; 285.5 ; 283.5$ and $288 \mathrm{eV}$ and consequently responsible for $\mathrm{Csp}^{2}, \mathrm{Csp}^{3}, \mathrm{C}-\mathrm{B}$ and $\mathrm{C}-\mathrm{O}$ carbon atom interaction [14].

$\mathrm{X}$-ray photoelectronic spectrum B1s can be considered as the peaks superposition characteristic of $\mathrm{B}-\mathrm{O}$, B-C and B-B interactions and located at energies 190.7, 189.4 and $190 \mathrm{eV}$ correspondently. 
There are peaks typical of $\mathrm{O}-\mathrm{C}, \mathrm{O}-\mathrm{O}$ and $\mathrm{O}-\mathrm{B}$ bonds in $\mathrm{X}$-ray photoelectronic spectrum of oxygen $\mathrm{O} 1 \mathrm{~s}$. As a result of statistical data processing of $\mathrm{C} 1 \mathrm{~s}$ XPE-spectrum it was found that integrated area share for $\mathrm{C}-\mathrm{O}$ bonds does not exceed $5 \%$.

XPS for boron doped CC ambiguously depend on $\mathrm{N}_{B}$ value in CC. At low boron $\mathrm{N}_{\mathrm{B}}(2.3$ at. \%) $\mathrm{B}-\mathrm{C}$ carbone bonds are mainly formed. With further $\mathrm{N}_{\mathrm{B}}$ growth $\mathrm{B}-\mathrm{B}$ bonds increase in the structure of composite $\mathrm{CC}$ occurs. However, at high $\mathrm{N}_{\mathrm{B}}$ value (43.2 at. \%) we observe carbon matrix restructuring with dominant $\mathrm{Csp}^{2}$ and carbide phases content in $\mathrm{CC}$ volume. There is some $\mathrm{C}$-sp $\mathrm{sp}^{3}$-peak shiftcenter (up to $\sim 0.3 \mathrm{eV}$ ) towards higher energies as well as the reduction of this peak half-width at $\mathrm{N}_{\mathrm{B}}$ increase in CC. It can be connected with the presence of more than one heterophase forming the structure in CC [15], as well as the development of competing forming processes in the coating layer of carbide compounds and boron oxide.

With $\mathrm{N}_{\mathrm{B}}$ growth we observe the reduction of $\mathrm{Csp}^{3}$ carbon atom bonds and considerable increase of B-C-bonds, characteristic of boron carbide in the coating. It can be assumed that $\mathrm{Csp}^{3}$ reduction of carbon clusters is caused by their replacement for boron carbide. It corresponds to the results of CC RS analysis where graphitization of carbon structure and orientation increase of carbon $\mathrm{Csp}^{2}$-clusters due to boron bonds with carbon atoms in $\mathrm{sp}^{3}$ hybridization state are observed. Such phase changes in $\mathrm{CC}$ with different $\mathrm{N}_{\mathrm{B}}$ values allow for their high mechanical properties preservation.

\section{Conclusion}

The structural properties of composite boron-carbon coatings obtained by ion-plasma synthesis are largely determined by the boron content in them. At a low concentration of NB (2.3 at.\%) Boron, bonds with carbon of the B-C type are predominantly formed. With the growth of $\mathrm{N}_{\mathrm{B}}$ in boron-doped carbon coating a grain structure is formed, its size and grain orientation regarding the surface of the substrate increase, resulting in a decrease in the coating layer surface roughness. An increase in the grain size of the structure of boron-doped UPs is caused by the high activity of agglomeration processes with the formation of boroncontaining microvolumes in the original one-component carbon material. With the subsequent growth of NB, there is an increase in the B-B bonds in the structure of the composite UP. Also, the increase of $\mathrm{N}_{\mathrm{B}}$ in carbon coating structure leads to the reduction of carbon phase content with $\mathrm{sp}^{3}$ hybridized bonds and is replaced by boron carbide clusters. It is confirmed by graphitization of carbon structure and increase of carbon Csp ${ }^{2}$ clusters due to chemical boron and carbon atoms interaction in the state with $\mathrm{sp}^{3}$ hybridized bonds. At a high NB value (43.2 at.\%), The structure of the carbon matrix is restructured with a predominant content of $\mathrm{Csp}^{2}$ and carbide phases in the volume.

The study was supported by the Chinese Ministry of Science and Technology (projects No.2016YFE0111800, for 2016-2019), as well as in the framework of the execution of the task 3.4.23 SPSI "Physical materials science, new materials and technologies» (Republic of Belarus) and by the Ministry of Science and Higher Education of Russian Federation (project No. 0706-2020-0022).

\section{References}

1 He D. Tailoring the mechanical and tribological properties of B4C/a-C coatings by controlling the boron carbide content / D. He, L. Shang, Z. Lu, G. Zhang, L. Wang, Q. Xue // Surface and Coatings Technology. - 2017. — Vol. 329. — P. 11-18. DOI: 10.1016/j.surfcoat.2017.09.017.

2 Cuong P.D. Effects of relative humidity on tribological properties of boron carbide coating against steel / P.D. Cuong, HyoSok Ahn, Eui-Sung Yoon, Kyung-Ho Shin // Surface and Coatings Technology. — 2006. - Vol. 201. — P. 4230-4235. DOI: 10.1016/j.surfcoat.2006.08.093.

3 Solozhenko V.L. Synthesis of superhard cubic $\mathrm{BC}_{2} \mathrm{~N} /$ V.L. Solozhenko, D. Andrault, G. Fiquet, M. Mezouar, D.C. Rubie // Applied Physics Letters. - 2001. — Vol. 78. — P. 1385-1387. DOI: 10.1063/1.1337623.

4 Chepkasov S. Properties of ta-C coatings prepared by pulsed cathodic arc source at various distances / S. Chepkasov, A. Zolkin, D. Piliptsou, E. Gladkikh, K. Kravchuk // IOP Conf. Series: Journal of Physics: Conf. Series. — 2018. — Vol. 1115. — P. 032066. DOI: 10.1088/1742-6596/1115/3/032066.

5 Wang S. Structure and properties of polyaniline nanocomposite coatings containing gold nanoparticles formed by low-energy electron beam deposition / S. Wang, A.A. Rogachev, V.A. Yarmolenko, A.V. Rogachev, Jiang Xiaohong, M.S. Gaur, A.P. Luchnikov, O.V. Galtseva, S.A. Chizhik // Applied Surface Science. - 2018. - Vol. 428. — P. 1070-1078. DOI: 10.1016/j.apsusc.2017.09.225.

6 Luchnikov P.A. Deformable Polymer Dielectric Films in Phase Light Modulators / P.A. Luchnikov, V.V. Vetrova, N.P. Zubkov, O.A. Surzhikova, N.I. Chernova // IOP Conference Series: Materials Science and Engineering. — 2017. — Vol. 189. - P. 012027. DOI: $10.1088 / 1757-899 X / 189 / 1 / 012027$. 
7 You M.S. Low temperature growth of highly transparent nanocrystalline diamond films on quartz glass by hot filament chemical vapor deposition / M.S. You, F.C.N. Hong, Y.R. Jeng, S.M. Huang // Diamond and Related Materials. - 2009. — Vol. 18. - P. 155-159.

8 Dvorkin V.V. Use of ultrafine-dispersed nanodiamond for selective deposition of boron-doped diamond films / V.V. Dvorkin, N.N. Dzbanovskii, N.V. Suetin, A.Yu. Yur'ev, A.F. Pal', P.Ya. Detkov // Physics of the Solid State. - 2004. Vol. 46. - P. 729-732. DOI: 10.1134/1.1711460.

9 Mori H. Low Friction Property of Boron Doped DLC under Engine Oil / H. Mori, M. Tohyama, M. Okuyama, T. Ohmori, N. Ikeda, K. Hayashi // Tribology Online. — 2017. — Vol. 12, № 3. - P. 135-140. DOI: 10.2474/trol.12.135.

10 Sikora A. Structural and electrical characterization of boron containing diamond-like carbon films deposited by femtosecond pulsed laser ablation / A. Sikora, A. Berkesse, O. Bourgeois, J.-L. Garden, C. Guerret-Piécourt, J.-N. Rouzaud, A.-S. Loir, F. Garrelie, C. Donnet // Solid State Sci. - 2009. — Vol. 11. - P. 1738-1741. DOI: 10.1016/j.solidstatesciences.2008.07.013.

11 Liza S. Deposition of boron doped DLC films on TiNb and characterization of their mechanical properties and blood compatibility / S. Liza, J. Hieda, H. Akasaka, N. Ohtake, Yu. Tsutsumi, A. Nagai, T. Hanawa // Science and Technology of Advanced Materials. - 2017. - Vol. 18, No. 1. - P. 76-87. DOI: 10.1080/14686996.2016.1262196.

12 Zhang L.L. Synthesis and characterization of boron incorporated diamond-like carbon thin films / L.L. Zhang, Q. Yang, Y. Tang, L. Yang, C. Zhang, Y. Hu, X. Cui / Thin Solid Films. - 2015. - Vol. 589. - P. 457-464. DOI: 10.1016/j.tsf.2015.05.067.

13 Buzhinskij O.I. Plasma deposition of boron films with high growth rate and efficiency using carborane / O.I. Buzhinskij, V.G. Otroshchenko, D.G. Whyte, M. Baldwin, R.W. Conn, R.P. Doerner, R. Seraydarian, S. Luckhardt, H. Kugel, W.P. West // Journal of Nuclear Materials. - 2003. — Vol. 313-316. - P. 214-218. DOI: 10.1016/S0022-3115(02)01482-4.

14 Panwar O.S. Characterization of Boron- and Phosphorous Incorporated Tetrahedral Amorphous Carbon Films Deposited by the Filtered Cathodic Vacuum Arc Process / O.S. Panwar, M.A. Khan, M. Kumar, S.M. Shivaprasad, B.S. Satyanarayana, P.N. Dixit, R. Bhattacharyya // Jpn. J. Appl. Phys. — 2009. — Vol. 48. — P. 065501. DOI: 10.1143/jjap.48.065501.

15 Белянин А.Ф. Наноструктурированные углеродные материалы в эмиссионной электронике / А.Ф. Белянин, В.В. Борисов, А.С. Багдасарян // Рос. технол. журн. — 2017. - Т. 5, № 3. - C. 22-40. DOI: 10.32362/2500-316X-2017-5-3-22-40.

Д.Г. Пилипцов, А.С. Руденков, А.В. Рогачев, Цзян Сяо Хун, Е.А. Кулеш, А.П. Суржиков, А.П. Лучников, О.А. Фролова

\title{
Бормен легирленген көміртекті композициялық материалдардың құрылымдық қасиеттері
}

\begin{abstract}
Мақалада бордың құрамына байланысты ион-плазмалық синтез нәтижесінде алынған бор-көміртек композицияларының морфологиясы, химиялық және фазалық құрамы қарастырылған. Бормен байланған көміртек жабынының (КЖ) үлгілері вакуумдық қондырғыда импульсті көміртегі плазмасынан көміртегі қабатының түсуімен және бор атомдары ағымының тұтасуымен алынған. Алынған композициялық КЖ үлгілерінде әртүрлі концентрациясы бар бор атомдары, атап айтқанда 2,3\% болды, олар а- $\mathrm{C}_{91,2}: \mathrm{B}_{2,3}$, a-C $\mathrm{C}_{79,3}: \mathrm{B}_{17,4}-17,4$ ат.\%, a-C $\mathrm{C}_{53,3}: \mathrm{B}_{43,2}-43,2$ ат.\%. Көміртекті құрылымдар және көміртек кластерлерінің графитизациясы рентгендік фотоэлектронды спектроскопия (XPS) және раман спектроскопиясымен зерттелді. КЖ құру кезінде көміртек пен бордың химиялық өзара әрекеттесуі мақсатында C1s, B1s, O1s атомдарының көміртегі, бор және оттегі энергетикалық күйлері үшін XPS математикалық өңдеу жүргізілді. XPS C1s 284,5-де орналасқан орталықтары бар шыңдардың суперпозициясы ретінде ұсынылды; 285,5; 283,5 және 288 эВ, демек, $\mathrm{Csp}^{2}, \mathrm{Csp}^{3}, \mathrm{C}-\mathrm{B}$ және $\mathrm{C}-\mathrm{O}$ көміртек атомдарының өзара әрекеттесуіне жауап береді. $\mathrm{N}_{\mathrm{B}}$ өсуімен бормен қапталған көміртекті жабындыда түйіршікті құрылым пайда болады, оның мөлшері мен астықтың субстрат беткейінің ұлғаюына қарай бағдарлануы қабаттасу қабатының беттік кедір-бұдырының төмендеуіне әкеледі.
\end{abstract}

Кілт сөздер: композициялық көміртегі жабыны, бор тамшысының пайда болуы, атомдық күш микроскопиясы, рентгендік фотоэлектронды спектроскопия, раман спектроскопиясы, кластерлер, бор карбиді.

Д.Г. Пилипцов, А.С. Руденков, А.В. Рогачев, Цзян Сяо Хун, Е.А. Кулеш, А.П. Суржиков, А.П. Лучников, О.А. Фролова

\section{Структурные свойства углеродных композиционных материалов, легированных бором}

В статье рассмотрены морфология, химический и фазовый состав композиционных бороуглеродных покрытий, полученных ионно-плазменным синтезом, в зависимости от содержания бора. Образцы углеродного покрытия (УП), легированного бором, были получены в вакуумной установке комбиниро- 
ванным способом в сочетании с осаждением углеродного слоя из импульсной углеродной плазмы и его легированием потоком атомов бора. Полученные образцы композиционных УП содержали внедренные атомы бора с различной концентрацией $\left(\mathrm{N}_{\mathrm{B}}\right)$, а именно 2,3 ат.\% содержались в $\mathrm{a}-\mathrm{C}_{91,2}: \mathrm{B}_{2,3}$, в $\mathrm{a}-\mathrm{C}_{79,3}: \mathrm{B}_{17,4}-17,4$ ат.\%, в $\mathrm{a}-\mathrm{C}_{53,3}: \mathrm{B}_{43,2}-43,2$ ат.\%. Структуры углерода и графитизация углеродных кластеров были исследованы методами рентгеновской фотоэлектронной спектроскопии (XPS) и рамановской спектроскопии. С целью химического взаимодействия между углеродом и бором при создании УП была проведена математическая обработка XPS для энергетических состояний C1s, B1s, O1s атомов углерода, бора и кислорода. XPS C1s была представлена как суперпозиция пиков с центрами, расположенными в 284,$5 ; 285,5 ; 283,5$ и 288 эВ, и, следовательно, они являлись ответственными за взаимодействие атомов углерода $\mathrm{Csp}^{2}, \mathrm{Csp}^{3}, \mathrm{C}-\mathrm{B}$ и $\mathrm{C}-\mathrm{O}$. С ростом $\mathrm{N}_{\mathrm{B}}$ в углеродном покрытии, легированном бором, образуется зернистая структура, увеличиваются ее размер и ориентация зерен относительно поверхности подложки, что приводит к уменьшению шероховатости поверхности слоя покрытия.

Ключевые слова: композитные углеродные покрытия, каплеобразование бора, атомно-силовая микроскопия, рентгеновская фотоэлектронная спектроскопия, комбинационная спектроскопия, кластеры, карбид бора.

\section{References}

1 He, D., Shang, L., Lu, Z., Zhang, G., Wang, L., \& Xue, Q. (2017). Tailoring the mechanical and tribological properties of B4C/a-C coatings by controlling the boron carbide content. Surface and Coatings Technology, 329, 11-18, DOI: 10.1016/j.surfcoat.2017.09.017.

2 Cuong, P.D, Hyo-Sok, A., Eui-Sung, Y., \& Kyung-Ho, Sh. (2006). Effects of relative humidity on tribological properties of boron carbide coating against steel. Surface and Coatings Technology, 201, 4230-4235, DOI: 10.1016/j.surfcoat.2006.08.093.

3 Solozhenko, V.L. Andrault, D., Fiquet, G., Mezouar, M., \& Rubie, D.C. (2001). Synthesis of superhard cubic BC2N. Applied Physics Letters, 78, 1385-1387, DOI: 10.1063/1.1337623.

4 Chepkasov, S., Zolkin, A., Piliptsou, D., Gladkikh, E., \& Kravchuk, K. (2018). Properties of ta-C coatings prepared by pulsed cathodic arc source at various distances. IOP Conf. Series: Journal of Physics: Conf. Series, 1115, 032066, DOI: 10.1088/1742-6596/1115/3/032066.

5 Wang, S., Rogachev, A.A., Yarmolenko, V.A., Rogachev, A.V., Jiang Xiaohong, \& Gaur, M.S. et al. (2018). Structure and properties of polyaniline nanocomposite coatings containing gold nanoparticles formed by low-energy electron beam deposition. Applied Surface Science, 428, 1070-1078, DOI: 10.1016/j.apsusc.2017.09.225.

6 Luchnikov, P.A., Vetrova, V.V., Zubkov, N.P., Surzhikova, O.A, \& Chernova, N.I. (2017). Deformable Polymer Dielectric Films in Phase Light Modulators. IOP Conference Series: Materials Science and Engineering, 189, 012027, DOI: 10.1088/1757$899 \mathrm{X} / 189 / 1 / 012027$.

7 You, M.S., Hong, F.C.N., Jeng, Y.R., \& Huang, S.M. (2009). Low temperature growth of highly transparent nanocrystalline diamond films on quartz glass by hot filament chemical vapor deposition. Diamond and Related Materials, 18, 155-159, DOI: 10.1016/j.diamond.2008.07.015.

8 Dvorkin, V.V., Dzbanovskii, N.N., Suetin, N.V., Yur'ev, A.Yu., Pal', A.F., \& Detkov, P.Ya. (2004). Use of ultrafinedispersed nanodiamond for selective deposition of boron-doped diamond films. Physics of the Solid State, 46, 729-732, DOI: $10.1134 / 1.1711460$.

9 Mori, H., Tohyama, M., Okuyama, M., Ohmori, T., Ikeda, N., \& Hayashi, K. (2017). Low Friction Property of Boron Doped DLC under Engine Oil. Tribology Online, 12(3), 135-140, DOI: 10.2474/trol.12.135.

10 Sikora, A., Berkesse, A., Bourgeois, O., Garden, J.-L., Guerret-Piécourt, C., \& Rouzaud, J.-N.et al. (2009). Structural and electrical characterization of boron containing diamond-like carbon films deposited by femtosecond pulsed laser ablation. Solid State Sci., 11, 1738-1741, DOI: 10.1016/j.solidstatesciences.2008.07.013.

11 Liza, S., Hieda, J., Akasaka, H., Ohtake, N., Tsutsumi, Yu., \& Nagai, A. et al. (2017). Deposition of boron doped DLC films on TiNb and characterization of their mechanical properties and blood compatibility. Science and Technology of Advanced Materials, 18(1), 76-87. DOI: 10.1080/14686996.2016.1262196.

12 Zhang, L.L., Yang, Q., Tang, Y., Yang, L., Zhang, C., \& Hu, Y. et al. (2015). Synthesis and characterization of boron incorporated diamond-like carbon thin films. Thin Solid Films, 589, 457-464, DOI: 10.1016/j.tsf.2015.05.067.

13 Buzhinskij, O.I., Otroshchenko, V.G., Whyte, D.G., Baldwin, M., Conn, R.W., \& Doerner, R.P. et al. (2003). Plasma deposition of boron films with high growth rate and efficiency using carborane. Journal of Nuclear Materials, 313-316, 214-218, DOI: 10.1016/S0022-3115(02)01482-4.

14 Panwar, O.S., Khan, M.A., Kumar, M., Shivaprasad, S.M., Satyanarayana, B.S., \& Dixit, P.N. et al. (2009). Characterization of Boron- and Phosphorous Incorporated Tetrahedral Amorphous Carbon Films Deposited by the Filtered Cathodic Vacuum Arc Process. Jpn. J. Appl. Phys., 48, 065501, DOI: 10.1143/jjap.48.065501.

15 Belyanin, A.F., Borisov, V.V., \& Bagdasaryan, A.S. (2017). Nanostrukturirovannye uhlerodnye materialy v emissionnoi elektronike 「Nanostructured carbon materials in emission electronics]. Rossiiskii tekhnolohicheskii zhurnal — Russian Technological Journal, 5(3), 22-40, DOI: 10.32362/2500-316X-2017-5-3-22-40 [in Russian]. 